\title{
Changes in Soil Properties after Soil Washing of Metal-contaminated Soil near the former Janghang Smelter
}

\author{
Keong-Hyeon An ${ }^{\oplus}$. Songhee Kim $^{\oplus}$. Seung-Woo Jeong ${ }^{\dagger}$
}

Department of Environmental Engineering, Kunsan National University

(Received September 8, 2020; Revised October 6, 2020; Accepted October 12, 2020)

Objectives: Changes in soil properties after washing of metal-contaminated soil near the former Janghang Smelter were investigated in this study. Contaminated input soils and remediated output soils were sampled from three different soil washing plants and analyzed for soil physical and chemical properties. Soil quality was evaluated by the soil fertilization guideline suggested by the Korea Rural Development Administration (KRDA). This study revealed the necessity of soil quality management for the remediated soil as an ecosystem member.

Methods: Three soil washing plants (1OU, 2OU, 3OU) were commonly divided into the five steps: 1) the particle separation (crushing and grinding etc.) $\rightarrow 2$ ) soil particle classification (big stone, fine soil, minimal fine soil) $\rightarrow 3$ ) chemical washing (fine soil) $\rightarrow 4$ ) neutralization of washed soil $($ lime) $\rightarrow 5$ ) return-back to the original position. The separating minimum particle diameters of the $1 \mathrm{OU}, 2 \mathrm{OU}$, and $3 \mathrm{OU}$ washing processes were $5 \mu \mathrm{m}, 20 \mu \mathrm{m}$, and $10 \mu \mathrm{m}$, respectively, and the chemical washing solutions used were respectively $0.1 \mathrm{M} \mathrm{H}_{2} \mathrm{SO}_{4}, 0.5 \mathrm{M} \mathrm{H}_{2} \mathrm{SO}_{4} / 0.5$ $\mathrm{M} \mathrm{H}_{3} \mathrm{PO}_{4}$, and $0.1 \mathrm{~N} \mathrm{NaOH}-\mathrm{Na}_{2} \mathrm{CO}_{3}$ (alkali reduction). Soils were collected before and after washing, air-dried, sieved with $<2 \mathrm{~mm}$ and analyzed for soil texture, bulk density, aggregate stability (AS), water holding capacity (WHC), $\mathrm{pH}$, electrical conductivity (EC), organic matter content (OM), total nitrogen (TN), available phosphate (AvP), cation exchange capacity (CEC), exchangeable cations (potassium, calcium, magnesium, sodium).

Results and Discussion: Sandy soil showed a big change in soil texture before and after soil washing, while there was no change in soil texture for fine soil. Sandy soil showed an increase in bulk density, a decrease in WHC, and a decrease in AS. The $\mathrm{pH}$ of remediated soil was affected by the type of washing chemical. The acidic washing processes (1OU, 2OU) resulted in low $\mathrm{pH}$ soils, while an alkali reduction process (3OU) showed high $\mathrm{pH}$ soil. The soil OM, TN, AvP and CEC decreased after soil washing. In the case of silty paddy soil, OM and TN were significantly reduced by washing. The most important change in soil property after washing was EC. After soil washing, the soil electrical conductivity increased sharply in all OUs : $1 \mathrm{OU} 0.51 \rightarrow 6.21 \mathrm{ds} / \mathrm{m}, 2 \mathrm{OU} 1.09 \rightarrow$ $3.73 \mathrm{ds} / \mathrm{m}$, 3OU $0.99 \rightarrow 9.30 \mathrm{ds} / \mathrm{m}$. The EC values of the contaminated soil before washing were all less than 2 $\mathrm{ds} / \mathrm{m}$, which is an appropriate agricultural level. However, EC was significantly increased after washing, implying a strong salty soil level. The soil quality evaluation results before and after washing showed that the soil quality of heavy-metal contaminated soil was apparently degraded by washing. The number of soil property in the optimal range before washing (contaminated soil) was 10, but the number decreased to 5 after washing (remediated soil).

Conclusions: Soil quality may be significantly changed after soil washing. The most noticeable change was the significant increase in the EC of soil and the soil health should be restored first to recycle the remediated soil. The important causes of changes in the soil quality were the separation of fine soil particles containing relatively high heavy metals from the bulk soil, soil disturbance by chemical washing solution and addition of high salts such as coagulants and $\mathrm{pH}$ adjust. Soil management schemes considering soil health should be soon prepared to restore the remediated soil back as an ecosystem member.

Keywords : Soil Washing, Heavy Metal, Soil Health, Remediated Soil, Electrical Conductivity, Soil Texture

The Korean text of this paper can be translated into multiple languages on the website of http://jksee.or.kr through Google Translator. 


\title{
연구논문
}

\section{옛 장항제련소 주변 중금속 오염토 세척공정 후 토양 특성 변화 연구}

\author{
안경현 ${ }^{\circledR} \cdot$ 김송희 $^{\circledR} \cdot$ 정승우 ${ }^{\dagger}$
}

군산대학교 환경공학과

서론 : (구)장항제련소 주변 비매입구역 중금속 오염토양에 대한 토양세척공정 적용 전, 후 토양특성 변화를 관찰하 였다. 3 개 다른 토양세척공정으로부터 토양세척공정 적용 전, 후 토양을 확보하여 토양 기본 특성을 분석하였고, 조사된 토양특성 결과는 농업진흥청에서 권장하고 있는 작물재배시비기준과 비교하여 토양 기능을 간접적으로 평 가하였다. 또한 본 연구는 오염토양 공정 적용 후 발생하는 정화토 관리 필요에 대해 토의하였다.

방법 : 3 개 토양세척공정(1OU, 2OU, 3OU)은 공통적으로 입도 분급(파쇄, 마쇄, 분쇄 등) $\rightarrow$ 물리적 선별(큰 돌, 미 세토, 최소 미세토) $\rightarrow$ 화학적 세척 $($ 미세토 $) \rightarrow$ 세척토 중화(소석회 $\rightarrow$ 세척토 혼합 및 원위치 등의 순으로 진행된 다. $1 \mathrm{OU}, 2 \mathrm{OU}, 3 \mathrm{OU}$ 세척공정의 최소 분류 입경은 각각 $5 \mu \mathrm{m}, 20 \mu \mathrm{m}, 10 \mu \mathrm{m}$ 이었으며, 사용된 세척액은 각각 0.1 $\mathrm{M} \mathrm{H}_{2} \mathrm{SO}_{4}, 0.5 \mathrm{M} \mathrm{H}_{2} \mathrm{SO}_{4} / 0.5 \mathrm{M} \mathrm{H}_{3} \mathrm{PO}_{4}, 0.1 \mathrm{~N} \mathrm{NaOH}-\mathrm{Na}_{2} \mathrm{CO}_{3}$ (알칼리환원법)이었다. 본 연구는 세척 전, 후 토양을 채취하여 풍건 후 입경 $2 \mathrm{~mm}$ 이하 토양에 대해 토성(texture), 용적밀도, 입단안정성, 보수력, $\mathrm{pH}$, 전기전도도, 유기 물함량, 총질소, 유효인산, 양이온교환능력, 치환성양이온(칼륨, 칼슘, 마그네슘, 나트륨) 등을 분석하였다.

결과 및 토의: 사질성 토양은 세척과정 중 토양 파쇄 및 분쇄과정으로 토성 변화가 크게 나타났지만 미사질성 토양 은 세척 후에도 토성 변화가 없었다. 토성 변화가 크게 나타난 사질성 토양은 용적밀도 증가, 보수력 감소, 입단의 안정성 감소를 보였다. 세척 후 토양 $\mathrm{pH}$ 는 사용된 세척액에 따라 영향을 받아 산성용액을 사용한 공정은 확연히 낮은 $\mathrm{pH}$ 를 보였고 알칼리용액을 사용한 경우 높은 $\mathrm{pH}$ 를 보였다. 세척 후 토양의 유기물함량, 전질소, 유효인산 및 $\mathrm{CEC}$ 등은 모두 감소하였다. 미사질 논토양의 경우 세척 후 유기물함량과 총질소 값이 확연하게 감소하였다. 세척 후 가장 두드러지게 변화된 토양특성은 전기전도도였다. 토양세척 후 토양 전기전도도는 $1 \mathrm{OU} 0.51 \rightarrow 6.21 \mathrm{ds} / \mathrm{m}$, $2 \mathrm{OU} 1.09 \rightarrow 3.73 \mathrm{ds} / \mathrm{m}, 3 \mathrm{OU} 0.99 \rightarrow 9.30 \mathrm{ds} / \mathrm{m}$ 로 모든 $\mathrm{OU}$ 에서 급격히 증가하였다. 세척 전 오염토양의 전기전도 도는 모두 적정수준인 $2 \mathrm{ds} / \mathrm{m}$ 이하였지만 토양세척 후 크게 증가하여 강한 염류토양 수치를 보였다. 장항지역 작 물별 시비처방기준으로 세척 전, 후 토양의 질을 평가한 결과 옛 장항제련소 주변 중금속 오염토는 세척(정화) 후 토양 질이 급격히 저하된 것으로 나타났다. $1 \mathrm{OU}, 2 \mathrm{OU}, 3 \mathrm{OU}$ 를 모두 통틀어 집계하면 세척 전(오염토) “적정” 범위 에 속한 토양 특성 값은 10 개였지만 세척 후(정화토) 5 개로 줄었다.

결론 : 토양세척 공정 적용으로 인한 토양 질 변화는 심하게 나타났다. 가장 큰 변화는 토양 전기전도도의 급격한 증가로 나타나 토양 세척토를 재활용하기 위해서는 토양의 건강성 회복이 먼저 이루져야 한다. 중금속 세척공정으 로 인한 급격한 토양 질 변화의 원인은 첫째, 중금속을 상대적으로 높게 함유한 미세토의 분리 및 폐기로 미세토가 빠져나간 것과 둘째, 화학세척액에 의한 토양교란이 이루어졌고, 셋째, 응집제 및 중화제 등 고농도 염을 사용하였 기 때문이다. 따라서 정화토를 생태계의 일원으로 다시 되돌려 보내기 위해 앞으로 토양으로서 기능을 회복시킬 수 있도록 제도적 정비와 공학적 노력이 필요하다.

주제어 : 토양세척, 중금속, 토양건강성, 정화완료토, 전기전도도, 토성

\section{1. 서론}

1996년 토양환경보전법 시행 이후 우리나라 토양환경 정 책은 토양의 체계적 관리를 위해 관련 대책을 계속 추진하 고 있다. 그동안 토양환경 정책은 토양오염 방지 및 오염토 양 관리 체계 구축에 노력하였다면 최근 시행된 제 2 차 토양
환경 보전 기본계획(2020-2029)에서는 토양의 생태학적 기 능을 보전하고자 토양 건강성 개념을 새롭게 도입하였다. ${ }^{1)}$ 앞으로 토양오염물질 기준에 의한 오염 여부뿐 아니라 토양 의 기능에 관한 연구와 관심이 늘어날 전망이다.

토양 건강성은 농업분야에서 활발히 연구되어졌다. 농업 생산성에 대한 척도로 Andrews et al. ${ }^{2)}$ 가 대표적 토양 건강 
성 평가체계 Soil Management Assesment Framework을 제 안한 이후 다양한 평가인자 개발에 관한 연구가 이루어지고 있다. ${ }^{3)}$ 최근 토양오염 정화이후 재활용에 관심이 높아지면 서 오염토양 및 정화토에 대한 건강성 평가 연구도 활발하 다. ${ }^{4-6)} \mathrm{Min}$ and Sung ${ }^{4}$ 은 사격장 중금속 오염토에 대한 세척 전, 후 토양 특성변화를 관찰한 결과 세척 후 모래함량 증가 로 생태학적 건강성이 떨어진 점을 보고하였다. Chae et al. ${ }^{5)}$ 은 (구)장항제련소 주변 중금속 오염토 세척 후 토양효소활 성도가 오염토보다 낮게 나타났음을 보고하였다. 세척 후 토양 건강성에 대한 전반적 평가에 관한 연구는 계속 보고 되고 있다.

충청남도 서천군에 위치한 (구)장항제련소는 과거 1936 1989 년까지 운영되면서 주변 토양을 중금속으로 오염시켰다. 2009 년 토양오염정밀조사 결과, 제련소 반경 $2 \mathrm{~km}$ 까지 비소, 카 드뮴, 납, 아연 니켈 등 중금속이 토양오염우려기준 및 토양 오염대책기준을 초과하였고 $2 \mathrm{~km}$ 외 표토에도 비소가 우려 기준을 초과하였다. ${ }^{7}$ 대한민국 정부는 오염이 심한 제련소 반경 $1.5 \mathrm{~km}$ 까지 토지를 매입하고 매입구역과 비매입구역 으로 구분하여 중금속 오염토양을 정화하였다. 먼저 비매입 구역(오염원으로부터 $1.5 \sim 4 \mathrm{~km}$ 해당)부터 토양세척공정을 주요공정으로 대지, 논, 밭 정화가 이루어졌고 이후 매입구 역 정화가 최근 2019년 완료되었다. 2013-2016년 동안 진행 된 비매입구역 정화는 정화대상지역을 3 개 공구(Operation Unit: 이하 “OU”)로 구분하여 각각 다른 토양세척공정을 적용하였다.

우리나라 토양정화 연구에서 토양오염 농도 저감에 관한 연구는 많이 보고되지만 토양 질(특성) 변화에 관한 연구는 많지 않다. 최근 완료된 (구)장항제련소 비매입구역 토양세 척사업은 대규모 토양세척 공정이 적용된 첫 사례지만 당 시 적용된 토양 정화 시스템에 관한 보고 자료가 부족하고 현장 세척토 토양 특성에 관한 연구사례 또한 찾아보기 어 렵다. 따라서 본 연구는 과거 장항 현장에 적용된 3 개의 토 양세척 공정에 대해 정리하여 자료로 남기고자 하였고 이 들 공정으로부터 양산된 정화토의 토양 질에 대해 연구하 였다.

본 연구는 (구)장항제련소 주변 비매입구역 중금속오염토 양에 대한 토양세척공정 적용 전, 후 토양특성 변화를 관찰 하였다. 각기 다른 토양세척공정이 적용된 3 개 공정으로부 터 토양세척공정 적용 전, 후 토양을 확보하여 토양 기본 특성을 분석하였고, 조사된 토양 특성결과는 농업진흥청에 서 권장하고 있는 작물재배시비기준과 비교하여 토양 기 능(또는 토양 질)을 평가하였다. 또한 본 연구는 오염토양 공정 적용 후 발생되는 정화토 관리에 대한 시사점을 토의 하였다.

\section{2. 실험방법}

\section{1. 연구 대상 토양의 확보 및 OU별 세척 특징}

본 연구대상 토양 시료는 (구)장항제련소 비매입구역 토 양세척공정에 투입되기 전 오염토와 토양세척 공정을 거친 정화토(이하 “세척토”)이다. 시료 채취는 2014년 하반기 정 화기간 동안 3 차 $(7 / 31,9 / 30,11 / 26)$ 에 걸쳐 각 $\mathrm{OU}$ 세척현장 에서 이루어졌다. 세척토는 3차에 걸쳐 채취하였고 오염토 는 2차 시료 채취에서만 이루어졌다.

각 $\mathrm{OU}$ 의 세척 방법에 차이가 존재하지만 공통적으로 입 도 분급(파쇄, 마쇄, 분쇄 등) $\rightarrow$ 물리적 선별(큰 돌, 미세토, 최소 미세토) $\rightarrow$ 화학적 세척(미세토) $\rightarrow$ 세척토 중화(소석 회) $\rightarrow$ 세척토 혼합 및 원위치 등의 순으로 진행되었다. 각 3 개 OU별 중금속 오염토양 세척공정에 대한 전반적인 흐름 은 Table 1에 정리하였다.

\subsection{1. $10 U$ 토양세척공정}

$1 \mathrm{OU}$ 의 토지이용도는 주로 대지였으며 일부 논, 밭이 포 함되어 있었다. $1 \mathrm{OU}$ 의 물리적 선별공정은 오염토를 입도별 5 단계로 선별하며 그 범위는 $50 \mathrm{~mm}$ 이상(드림워서 이용, 파쇄), $2 \mathrm{~mm}$ 이상(진동선별기 이용), $0.075(75 \mu \mathrm{m}) \mathrm{mm}$ 이 상 $(1,2$ 차 하이드로 사이클론 이용), $0.005(5 \mu \mathrm{m}) \mathrm{mm}$ 이상 (멀티 하이드로 사이클론 이용), $0.005(5 \mu \mathrm{m}) \mathrm{mm}$ 미만(멀 티 하이드로 사이클론 이용)이다.

선별된 $2 \mathrm{~mm}$ 이상 자갈 또는 큰 돌은 중금속 농도가 높 지 않아 세척과정에서 바로 분리되고, $0.005(5 \mu \mathrm{m}) \sim 2 \mathrm{~mm}$ 토양은 산 세척 대상으로 세척 후 토양검증을 통해 정화토 가 된다(Table 2 참조). 그리고 $0.005(5 \mu \mathrm{m}) \mathrm{mm}$ 미만의 미 세토에 대해 중금속농도가 비소(As) 우려 기준치 $25 \mathrm{ppm}$ 을 초과하면 폐기물매립지로 폐기되고, 기준치 이하이면 깨끗한 토양으로 분류되어 세척토와 섞는다. $1 \mathrm{OU}$ 의 세척제 는 $0.1 \mathrm{M} \mathrm{H}_{2} \mathrm{SO}_{4}$ 가 사용되었다.

\subsection{2. $2 \mathrm{OU}$ 토양세척공정}

$2 \mathrm{OU}$ 토지이용도는 논으로 3 개 $\mathrm{OU}$ 중 가장 미세한 토양 이다. $2 \mathrm{OU}$ 의 물리적 선별공정은 오염토를 입도별 7 단계로 나누며, 오염토를 파쇄하여 이물질제거기로 $10 \mathrm{~mm}$ 이상(1 단), $4.7 \mathrm{~mm}$ 이상(2단)으로 선별하고, 1차 다단입도선별기 에서 $0.075(75 \mu \mathrm{m}) \mathrm{mm}$ 이상, $0.075(75 \mu \mathrm{m}) \mathrm{mm}$ 미만, $0.02(20 \mu \mathrm{m}) \mathrm{mm}$ 미만으로 선별한다. 그리고 1차 다단입도 선별기에서 선별된 $0.075(75 \mu \mathrm{m}) \mathrm{mm}$ 이상의 토양에 대해 서는 2차 다단입도선별기에서 다시 표면분쇄 후 0.075 (75 $\mu \mathrm{m}) \mathrm{mm}$ 이상과 $0.075(75 \mu \mathrm{m}) \mathrm{mm}$ 미만으로 재구분한다.

선별된 $4.7 \mathrm{~mm}$ 이상의 이물질은 분리되고, 1 차 다단입도 선별기에서 나온 3 가지 입경의 토양 중 $0.075(75 \mu \mathrm{m}) \mathrm{mm}$ 이상의 토양은 표면분쇄기로 토양알갱이의 표면에 중금속 
Table 1. Soil washing unit processes applied for the metal-contaminated soil of the former Janghang Smelter area.

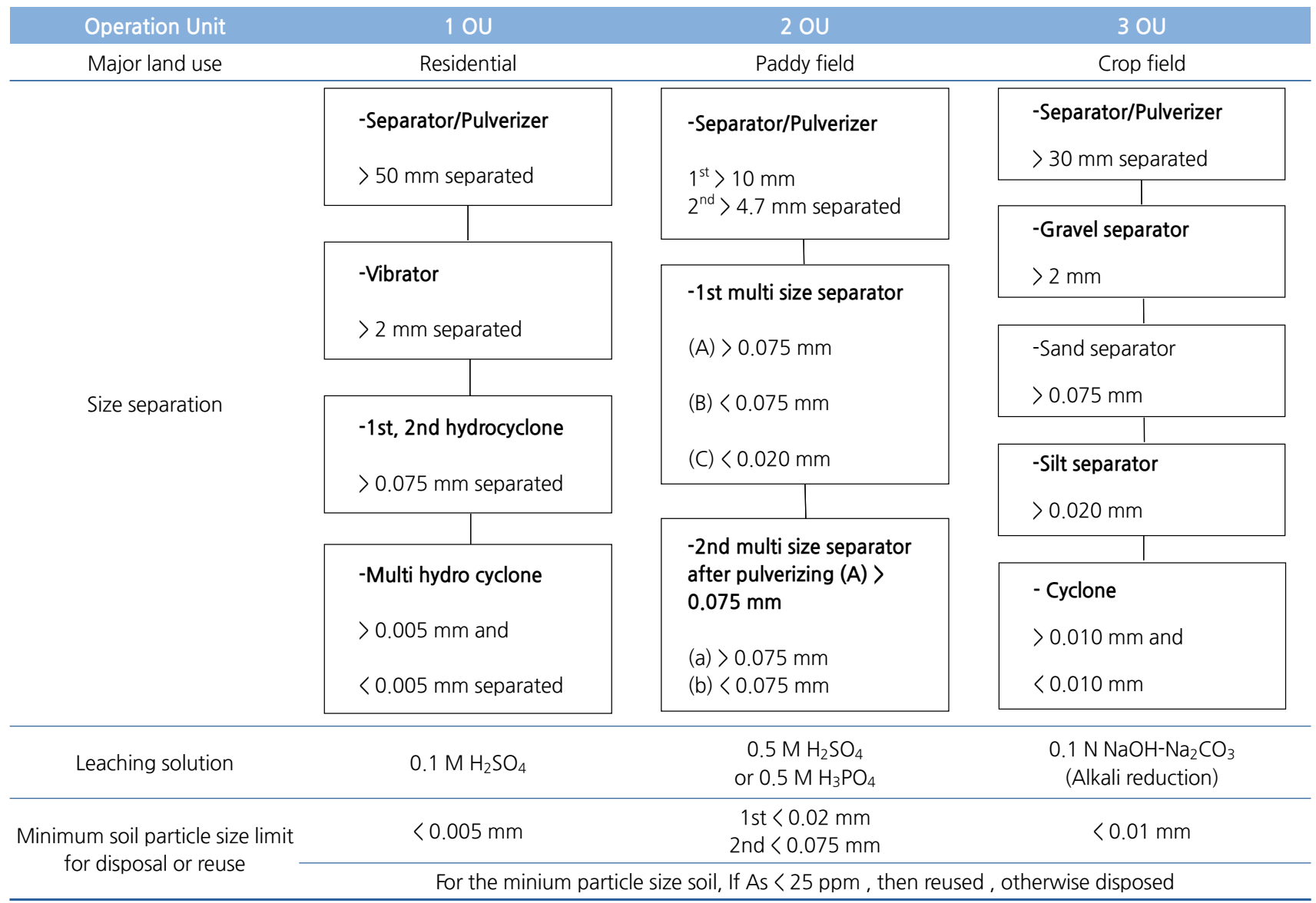

Table 2. Soil particle diameter range separated during soil washing processes. Soils corresponding these ranges were chemically washed.

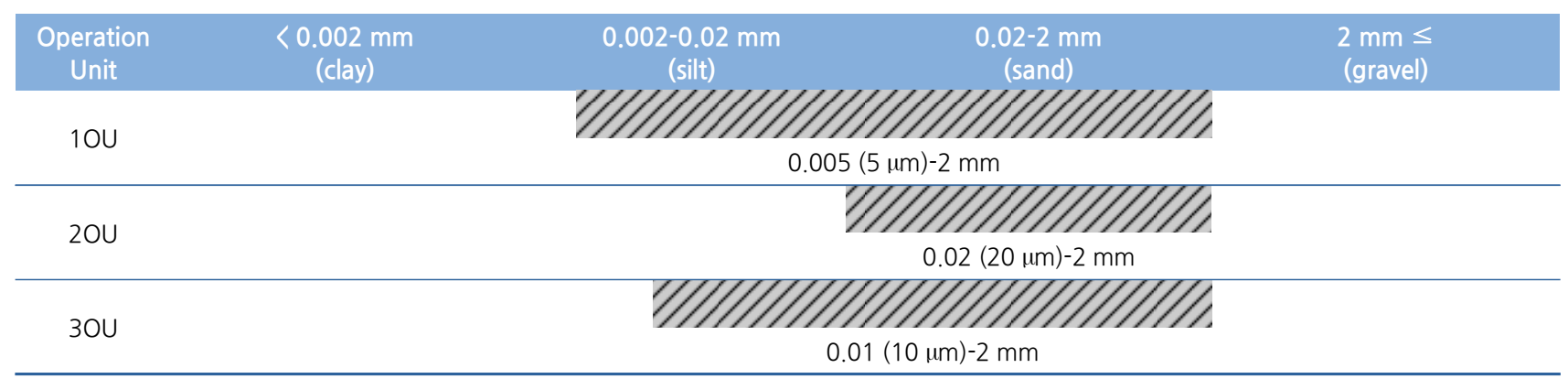

을 박리하여 2차 다단입도선별기로 들어가고, $0.02(20 \mu \mathrm{m})$ - $0.075(75 \mu \mathrm{m}) \mathrm{mm}$ 의 토양은 세척 후 정화토로 분류된다. 그리고 $0.02(20 \mu \mathrm{m}) \mathrm{mm}$ 미만의 미세토양에 대해 비소(As) 우려 기준치 $25 \mathrm{ppm}$ 을 초과하면 폐기물 매립지로 폐기되 고, 깨끗한 토양으로 분류되어 정화토와 섞는다. 또한, 표면 분쇄 후 2 차 다단입도선별기에서 나온 $0.075(75 \mu \mathrm{m})-2$ $\mathrm{mm}$ 의 토양은 세척 후 정화토로 구분되고, $0.075(75 \mu \mathrm{m})$ $\mathrm{mm}$ 미만의 토양은 중금속농도가 비소(As) 우려 기준치 25 $\mathrm{ppm}$ 을 초과하면 폐기되고, 기준치 이하이면 정화토로 분류 된다. $2 \mathrm{OU}$ 에서 세척되는 $0.02(20 \mu \mathrm{m})-2 \mathrm{~mm}$ 의 토양은 초
기오염토의 중금속농도가 비소(As) 대책 기준인 $75 \mathrm{ppm}$ 이 하이면 $0.5 \mathrm{M} \mathrm{H}_{2} \mathrm{SO}_{4}$ 로 세척되고, 이상이면 $0.5 \mathrm{M} \mathrm{H}_{3} \mathrm{PO}_{4}$ 로 세척된다.

\subsection{3. $3 \mathrm{OU}$ 토양세척공정}

$3 \mathrm{OU}$ 토지이용도는 밭이다. $3 \mathrm{OU}$ 의 물리적 선별공정은 오 염토를 입도별 6단계로 선별한다. 그 범위는 $30 \mathrm{~mm}$ 이상 (큰돌선별기 이용, 파쇄), $2 \mathrm{~mm}$ 이상(습식자갈선별기 이용), $0.075(75 \mu \mathrm{m}) \mathrm{mm}$ 이상(습식모래선별기 이용, 마쇄), 0.02 $(20 \mu \mathrm{m}) \mathrm{mm}$ 이상(습식실트선별 이용), $0.01(10 \mu \mathrm{m}) \mathrm{mm}$ 
Table 3. Land uses and major crops of the Janghang study sites.

\begin{tabular}{|c|c|c|c|}
\hline & $1 \mathrm{OU}$ & $2 \mathrm{OU}$ & $3 \mathrm{OU}$ \\
\hline Major land use & Residential & Paddy field & Crop field \\
\hline Major crops & Not applied & Cereals (rice, barley) & $\begin{array}{c}\text { Oilseed crop, } \\
\text { Potato, } \\
\text { Sweet potato, } \\
\text { Fruit vegetables, } \\
\text { Root vegetables, } \\
\text { Bulb vegetables, } \\
\text { Leaf vegetables }\end{array}$ \\
\hline
\end{tabular}

이상(고속원심상분리기 이용), $0.01(10 \mu \mathrm{m}) \mathrm{mm}$ 미만(고속 원심상분리기 이용)이다.

선별된 $2 \mathrm{~mm}$ 이상 자갈 또는 큰 돌은 중금속농도가 높지 않아 세척과정에서 바로 분리되고, $0.01(10 \mu \mathrm{m})-2 \mathrm{~mm}$ 의 입경은 세척대상이 되는 토양으로써 세척 후 검증을 통하여 정화토가 된다. 그리고 $0.01(10 \mu \mathrm{m}) \mathrm{mm}$ 미만의 미세토에 대해 중금속농도가 비소(As) 우려 기준치 $25 \mathrm{ppm}$ 을 초과하 면 폐기되고, 기준치 이하면 깨끗한 토양으로 분류되어 세척 토와 섞는다. $3 \mathrm{OU}$ 의 세척제는 $0.1 \mathrm{~N} \mathrm{NaOH}-\mathrm{Na}_{2} \mathrm{CO}_{3}$ (Alkali reduction)가 사용되었다.

\section{2. 토양의 물리 · 화학적 특성 분석}

토양의 물리적 특성 4 가지, 화학적 특성 7 가지를 분석하였 다. 실험항목은 토성(soil texture), 용적밀도(bulk density), 입 단안정성(aggregate stability), 보수력(water holding capacity), 수소이온농도 $(\mathrm{pH})$, 전기전도도(electical conductivity), 유기물 함량(organic matter content), 총질소(total nitrogen), 유효인산 (available phosphate), 양이온교환능력(cation exchange capacity), 치환성양이온(exchangeable cations: 칼륨, 칼슘, 마그네슘)으 로 총 11 가지 항목이다. 각 항목분석을 위해 공통적으로 토양 입경 $2 \mathrm{~mm}$ 이하 풍건세토를 사용하였다.

물리적 특성 항목에서 토성은 토양입자를 가열·분산시켜 서 $53 \mu \mathrm{m}$ 의 체에 거른 후 $1,000 \mathrm{~mL}$ 메스실린더에서 $10 \mathrm{~cm}$ 침강 깊이의 입자를 중량으로 측정하는 피펫법으로 실험하 였고 ${ }^{899}$, 용적밀도(bulk density)는 오염정화토양과 같이 굴 착되거나 원형을 유지하지 못한 교란된 토양에 적합한 실험 방법을 사용하였는데, 무게를 아는 $100 \mathrm{~mL}$ 메스실린더에 토양을 조금씩 부어 표면을 10 번씩 다지면서 $100 \mathrm{~mL}$ 까지 채워 무게를 잰 후 토양의 무게를 산정하였다. ${ }^{10,11)}$ 또한 입 단안정성(aggregate stability)은 증류수를 이용하여 $250 \mu \mathrm{m}$ 의 체에 얹힌 토양 $10 \mathrm{~g}$ 을 충분히 포화시킨 후 진탕·건조하 여 무게를 재는 실험방법을 사용하였고 ${ }^{12,13)}$, 보수력(water holding capacity)은 깔대기 필터에 담긴 토양에 증류수를 붓고 방치·정량하는 방법을 사용하였다. ${ }^{14,15)}$ 그리고 화학적 특성 항목에서 수소이온농도 $(\mathrm{pH})$ 는 풍건된 토양을 비커에 담아 증류수를 넣어 방치 후 $\mathrm{pH}$ 측정기로 측정하는 $\mathrm{MOE}^{16}$ 의 실험 방법을 사용하였고, 유기물함량(organic matter)은
LOI (loss on ignition) 법으로 $700^{\circ} \mathrm{C}$ 회화로에서 강열 감량 하여 무게 차를 재는 실험 방법을 사용하였다. ${ }^{17)}$ 나머지 화 학적 특성 항목에 대해서는 국립농업과학원에서 2010년도 에 발간된 토양화학분석법 ${ }^{18,19}$ 을 토대로 실험을 진행하였 다. 모든 분석은 동일 시료에 대해 3 회 이상 분석하였다.

\section{3. 토양 질 평가 기준}

본 연구에서는 토양 특성 12 항목을 분석하여 정화 전, 후 토양의 특성 변화를 관찰하였고, 분석된 물리·화학적 특성 값은 농촌진흥청의 작물별시비처방기준 ${ }^{20)}$ 과 비교하였다. 작 물별시비처방기준은 각 작물마다 처방기준이 다르므로 연 구대상 장항지역 재배작물에 대한 기준치를 선별하여 본 연 구에 활용하였다. 각 $\mathrm{OU}$ 의 토지이용도와 재배작물은 Table 3과 같다.

$1 \mathrm{OU}$ 는 농작물과 해당사항이 적은 대지 토양이 주로였지만 $2 \mathrm{OU}$ 는 곡류를 재배하는 논 토양, $3 \mathrm{OU}$ 는 유지작물, 서류, 과 채류 등을 재배하는 밭 토양이다. 작물별시비처방기준에 제 시된 총 7 개 평가항목 $\mathrm{pH}$, 전기전도도, 유기물함량, 유효인 산, 유효규산, 치환성양이온, 양이온교환능력) 값과 비교하여 세척 전, 후 토양을 “적정(Optimal)", "과다(Excessive)", “부 족(Lack)"으로 평가하였다. 평가에 적용된 기준치는 Table 4 에 정리하였다. 현재 토양 질 평가에 대한 절대적 기준은 없 다. 따라서 $1 \mathrm{OU}$ 는 대지 토양이지만 토양 질에 대한 상대적 평가기준으로 작물별시비처방기준을 단순히 적용하였다.

\section{3. 결과 및 고찰}

\section{1. 토양세척 전, 후 물리적 토양 특성 변화}

본 연구에서 조사된 세척 전, 후 토성(soil texture) 변화는 Fig. 1 과 같다. 세척 전, 후 토성은 $1 \mathrm{OU}$ 가 사질양토(sandy loam)에서 양질사토(loamy sand), 2OU는 미사질식양토 (silty clay loam)에서 그대로 미사질식양토(silty clay loam), 3OU는 모래(sand)에서 사질양토(sandy loam)로 비교적 토 양 입경이 굵은 $1 \mathrm{OU}$ 와 $3 \mathrm{OU}$ 에서 토성 변화가 현저히 일어 났다. $1 \mathrm{OU}$ 의 경우 모래(sand)가 $7 \%$ 증가, 미사(silt)와 점토 (clay) 함량이 각각 $3 \%$ 씩 감소하였고, $2 \mathrm{OU}$ 의 경우 모래와 점토가 각각 $3 \%, 2 \%$ 씩 감소, 미사가 $5 \%$ 증가하였고, $3 \mathrm{OU}$ 
Table 4. Soil fertilization prescription guidelines selected for Janghang agricultural crops from the guidelines suggested by Korea Rural Development Administration (KRDA).

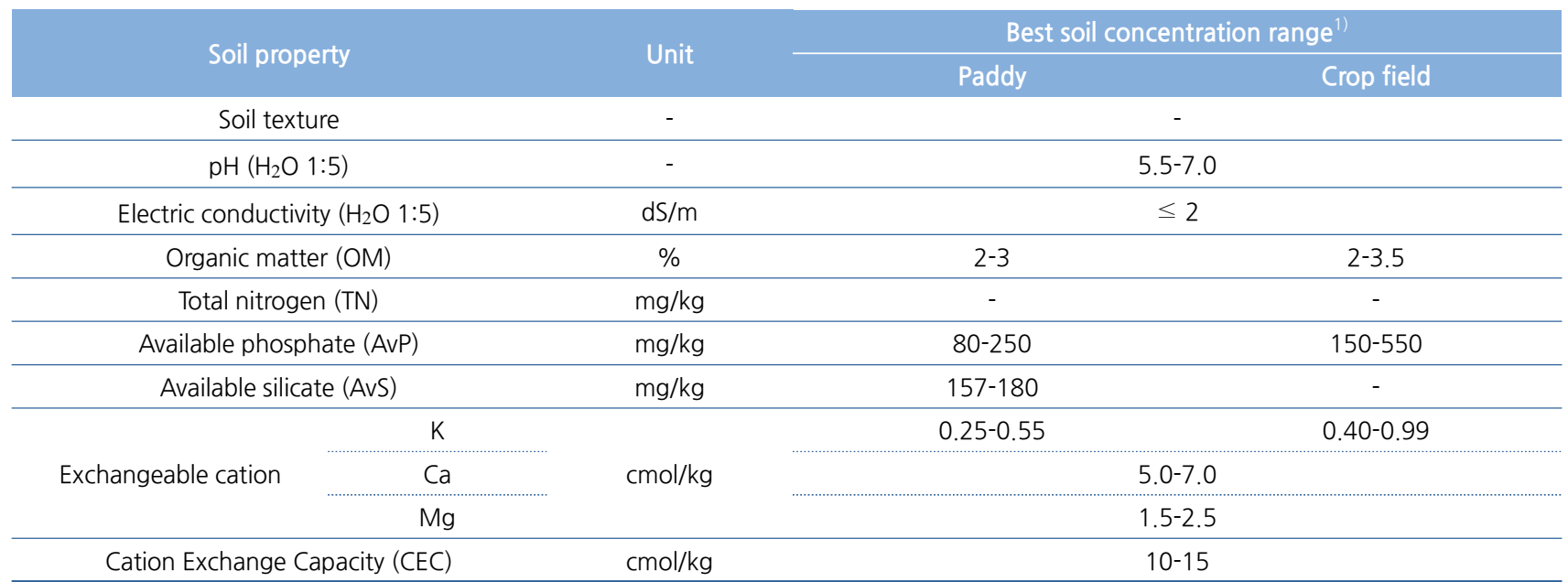

\footnotetext{
1) Selected crops: Cereals (rice, barley), Oilseed crop, Potato, Sweet potato, Fruit vegetables, Root vegetables, Bulb vegetables, Leaf vegetables
}

에서 모래는 $16 \%$ 감소, 미사와 점토는 각각 $15 \%, 1 \%$ 씩 증 가하였다.

토양세척으로 인한 토성 변화 원인은 크게 두 가지로 분 석된다. 첫째, 진동 파쇄과정에서 토양입자가 파쇄되거나 마모되어 토양 입자 크기에 변화가 있었다. 둘째, 최소미세 토로 분리된 토양 중 중금속 농도가 우려기준치보다 높아 최종 폐기되는 미세토 비중이 높은 경우 미세토가 빠져 전 체 토성에 영향을 미친다. Table1에 제시된 각 $\mathrm{OU}$ 에서 분 리 가능한 최소입경 이하 미세토는 중금속 우려기준 이상이 면 폐기물 매립지로 폐기되며 기준치를 만족하면 화학세정 공정을 거친 세척토와 다시 합쳐져 최종 정화토가 된다. 현 재 토성 데이터로 보면 3OU에서 파쇄와 마모가 가장 심하 게 이루어져 모래가 $16 \%$ 감소한 반면 마모되어 새롭게 생 긴 미사가 $15 \%$ 증가하였다. 토양 조성 데이터로 보면 토성 이름의 변화는 일어났지만 각 세부 토양 조성은 3공구에서 미사 함량변화가 $15 \%$ 변화된 것 이외 나머지 조성 변화는 그다지 크지 않다. 특히 미사와 점토함량 변화는 한 자리 숫 자로 크지 않다. 이는 최종 폐기되어 시스템 밖으로 빠져 나 간 미세토양의 양이 크지 않았고 대부분 미세토가 세척 후 다시 최종 정화토로 합쳐져 혼합된 것으로 보인다.

Fig. 1 에 나타낸 바와 같이 토양용적밀도는 3 개 OU 모두 세척 후 소폭 증가하는 추세를 보였다. 원래 오염토양에 단 단하게 뭉쳐있던 흙덩어리나 부서지기 쉬운 돌덩어리가 파 쇄나 분급 과정에서 토양입자가 부서져 용적밀도가 증가한 것으로 보인다. 용적밀도와 공극률은 일반적으로 가역적 관 계로 알려져 있다. ${ }^{21,22)}$

보수력은 사질성 토양인 $1 \mathrm{OU}$ 와 $3 \mathrm{OU}$ 가 미사와 점토함량 이 $90 \%$ 이상인 $2 \mathrm{OU}$ 미사질 토양에 비해 낮게 나타났다. 세 척 후 보수력은 $1 \mathrm{OU}$ 와 $3 \mathrm{OU}$ 사질성 토양에서는 약간 감소 하였지만, 미사질 토양인 $2 \mathrm{OU}$ 에서는 소폭 증가하였다. 보
수력은 토양 내 물과 영양분의 흡수정도를 나타내므로 식물 의 생장에 직접적 영향을 미칠 수 있다. ${ }^{19,23)}$

입단 안정성 결과는 보수력과 유사한 세척 전, 후 결과를 보였다. 사질성 토양인 $1 \mathrm{OU}$ 에서 $69 \rightarrow 54 \%, 3 \mathrm{OU}$ 에서 70 $\rightarrow 47 \%$ 로 감소되었지만, 미사질성 토양인 $2 \mathrm{OU}$ 에서 $61 \rightarrow$ $63 \%$ 로 미미하게 변화하였다. 입단 안정성도 토성에 따라 크게 영향을 받는다. 점토 함량이 높은 토양은 광물 입자 간 지속적인 팽창을 통해 입단화를 가져오지만 사질성 토양은 입자 간 뭉침이 적어진다. ${ }^{24,25)} 1 \mathrm{OU}$ 와 $3 \mathrm{OU}$ 는 당초 점토 함 량이 낮은 오염토가 세척 후 점토함량 비중이 더 낮아져 입 단안정성은 급격히 감소하였다.

정리해 보면, 모래 함량이 높은 사질성 토양에서는 토양 기능에서 중추적인 역할을 하는 점토 함량이 상대적으로 적 은데다 세척 후 오히려 미세토가 빠져나가 용적밀도 증가, 보수력 감소, 입단의 안정성 감소와 같은 영향을 받았다.

\section{2. 토양세척 전, 후 화학적 토양 특성 변화}

Fig. 2는 토양세척 전, 후 $\mathrm{pH}$, 전기전도도, 유기물함량, 총 질소, 유효인산 변화를 분석하였다. 먼저, 토양세척 후 토양 $\mathrm{pH}$ 는 $1 \mathrm{OU}$ 와 $2 \mathrm{OU}$ 에서 감소, $3 \mathrm{OU}$ 에서 증가하였다. 산성용 액을 세척액으로 사용한 $1 \mathrm{OU}$ 와 $2 \mathrm{OU}$ 는 확연히 낮은 $\mathrm{pH}$ 를 나타냈고 알칼리용액을 사용한 $3 \mathrm{OU}$ 의 $\mathrm{pH}$ 는 오히려 증가하 였다. 또한, 모든 $\mathrm{OU}$ 에서 세척 후 토양 중화제로 $\mathrm{Ca}(\mathrm{OH})_{2}$ (소석회)를 사용하지만, 중화가 적절히 이루어지지 않은 경 우 여전히 낮은 $\mathrm{pH}$ 를 보인다.

토양세척 전, 후 토양 전기전도도는 $1 \mathrm{OU} \quad 0.51 \rightarrow 6.21$ $\mathrm{ds} / \mathrm{m}, 2 \mathrm{OU} 1.09 \rightarrow 3.73 \mathrm{ds} / \mathrm{m}$, 3OU $0.99 \rightarrow 9.30 \mathrm{ds} / \mathrm{m}$ 로 모 든 $\mathrm{OU}$ 에서 급격히 증가하였다. 세척 전 오염토양의 전기전 도도는 모두 적정수준인 $2 \mathrm{ds} / \mathrm{m}$ 이하였지만 토양세척 후 크 게 증가하여 강한 염류토양 수치를 보였다. 세척 후 토양 전 

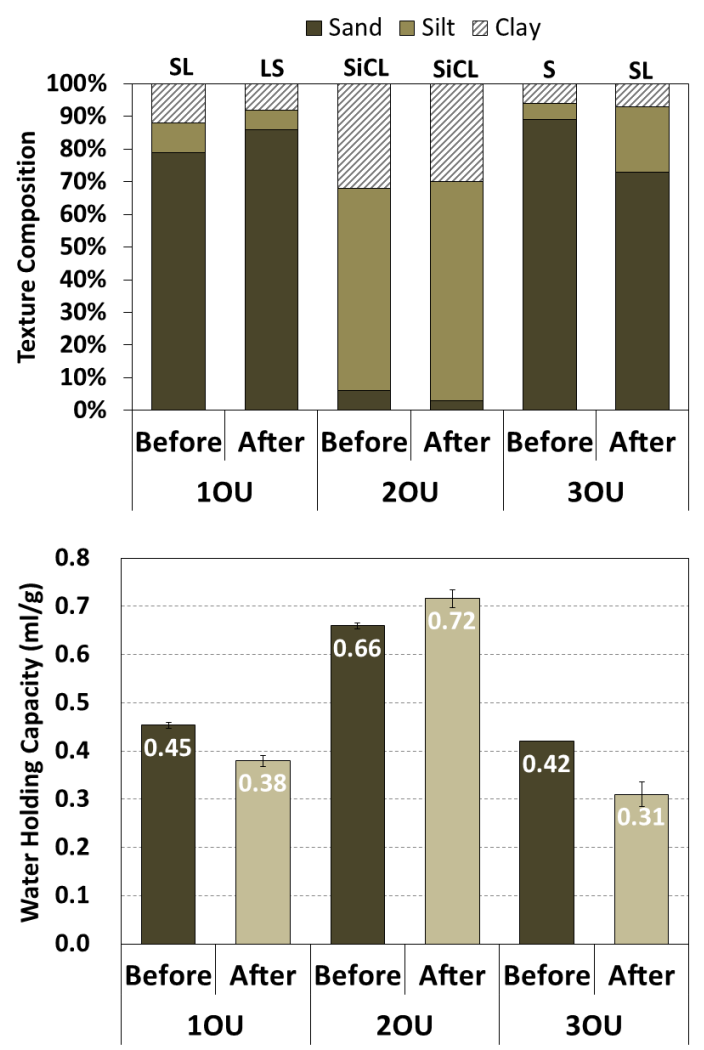
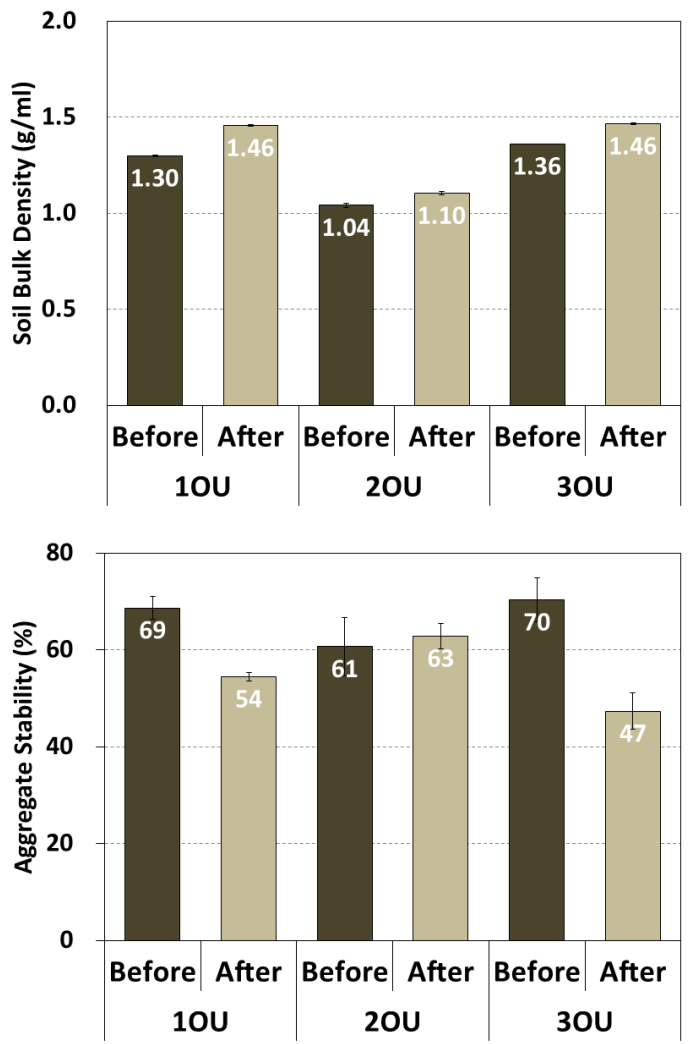

Fig. 1. Changes in soil physical properties before and after washing of the Janghang Smelter related metal contaminated soil (from three different operation units; 10U, $20 \mathrm{U}$ and 30U).

기전도도가 급격히 상승한 이유는 세척 후 탈수를 위해 고 농도 응집제를 사용하거나 $\mathrm{pH}$ 조정을 위해 고농도 염들이 투여되기 때문이다. 염류토양은 표층에 염류집적이 가속화 되어 식물 생장에 영향을 미칠 수 있다. ${ }^{22,26)}$

유기물함량은 Fig.2와 같이 세척 전, 후 10U와 30U에서 각각 $1.57 \rightarrow 1.45 \%, 1.15 \% \rightarrow 1.26 \%$ 로 큰 변화는 없었지만 논 토양인 $2 \mathrm{OU}$ 는 $4.34 \% \rightarrow 2.24 \%$ 로 급격히 감소하였다. $2 \mathrm{OU}$ 논 토양은 타 $\mathrm{OU}$ 에 비해 초기 유기물함량과 미세토 함량이 높아 세척으로 인한 유기물 손실이 매우 크게 나타 났다. 산세척으로 토양 유기물이 용해되고 최종 폐기되는 미세토량이 많아져 감소 폭이 크게 나타났다. Ko et al. ${ }^{27)}$ 은 토양 세척 공정이 수용액상 중금속 추출로 미세 입자 토양 내 유기물을 약 $39 \%$ 제거한다고 보고하였다.

총질소는 $1 \mathrm{OU}$ 와 $3 \mathrm{OU}$ 에서 세척 전, 후 각각 $301 \rightarrow 295$ $\mathrm{mg} / \mathrm{kg}, 253 \rightarrow 278 \mathrm{mg} / \mathrm{kg}$ 로 큰 변화가 없었지만 $2 \mathrm{OU}$ 논토 양에서는 세척 전, 후 각각 $1,423 \rightarrow 793 \mathrm{mg} / \mathrm{kg}$ 로 급격히 감 소하였다. 총질소의 변화는 유기물함량 변화와 유사한 추세 를 보였다. 유효인산의 경우 세척 후 그 수치가 감소하는 것 으로 나타났고 $1 \mathrm{OU}$ 감소 폭이 가장 크게 나타났다. 세척 전 토양 내 유기물, 총질소, 유효인산 함량이 상대적으로 높 은 경우 세척 후 감소 폭이 더 크게 나타났다.

양이온교환능력 변화 결과는 Fig. 2에 나타낸 바와 같이
$1 \mathrm{OU}$ 에서 $(12 \rightarrow 9 \mathrm{cmol} / \mathrm{kg}), 2 \mathrm{OU}$ 에서 $(27 \rightarrow 24 \mathrm{cmol} / \mathrm{kg})$, $3 \mathrm{OU}$ 에서 $(11 \rightarrow 8 \mathrm{cmol} / \mathrm{kg})$ 로 모든 $\mathrm{OU}$ 에서 세척 후 약간 감소하나 변화폭은 크지 않다. 미세토로 주로 구성되어 있 는 $2 \mathrm{OU} \mathrm{CEC}$ 가 사질토 $1 \mathrm{OU}$ 와 $3 \mathrm{OU}$ 의 $\mathrm{CEC}$ 보다 월등히 높 게 분포한다. $\mathrm{CEC}$ 를 결정짓는 점토의 비율이 Fig. 1 에 나타 낸 바와 같이 급격하게 변화하지 않아 CEC 변화 폭도 크지 않게 나타났다.

Fig. 3은 치환성양이온 $\mathrm{Ca}, \mathrm{Mg}, \mathrm{K}, \mathrm{Na}$ 분석 결과를 보여 준다. $3 \mathrm{OU}$ 의 $\mathrm{Na}$ 은 세척 전, 후 측정값이 $0.27 \rightarrow 15.72$ $\mathrm{cmol} / \mathrm{kg}$ 로 급격히 증가하였다. 이외 치환성양이온의 변화폭 은 크지 않았다. $3 \mathrm{OU}$ 는 $0.1 \mathrm{~N} \mathrm{NaOH}-\mathrm{Na}_{2} \mathrm{CO}_{3}$ 알칼리환원방 법에 의해 세척되어 많은 양의 $\mathrm{Na}$ 이 잔류하는 것으로 나타 났다. $3 \mathrm{OU}$ 의 염기포화도는 $394 \%$ 로 토양에 과도한 $\mathrm{Na}$ 이 흡 착 잔류하고 있는 것으로 보인다. 일반적으로 염기포화도가 높을수록 $\mathrm{pH}$ 도 높아진다. $3 \mathrm{OU}$ 토양의 $\mathrm{pH}$ 상승도 알칼리환 원제 $\left(0.1 \mathrm{M} \mathrm{NaOH}-\mathrm{Na}_{2} \mathrm{CO}_{3}\right)$ 세척에 의한 염기포화도 상승에 의한 결과로 보인다. 산세척이 이루어진 $1 \mathrm{OU}$ 와 $2 \mathrm{OU}$ 에서의 염기포화도는 세척 전보다 증가하였다. 염기포화도가 약간 증가한 반면 Fig. 1 에 나타낸 바와 같이 $1 \mathrm{OU}$ 와 $2 \mathrm{OU}$ 의 $\mathrm{pH}$ 는 오히려 감소하여 염기포화도 증가에 의한 $\mathrm{pH}$ 증가 폭보 다 산세척으로 인한 $\mathrm{pH}$ 감소 영향이 더 크게 나타난 것으 로 판단된다. 

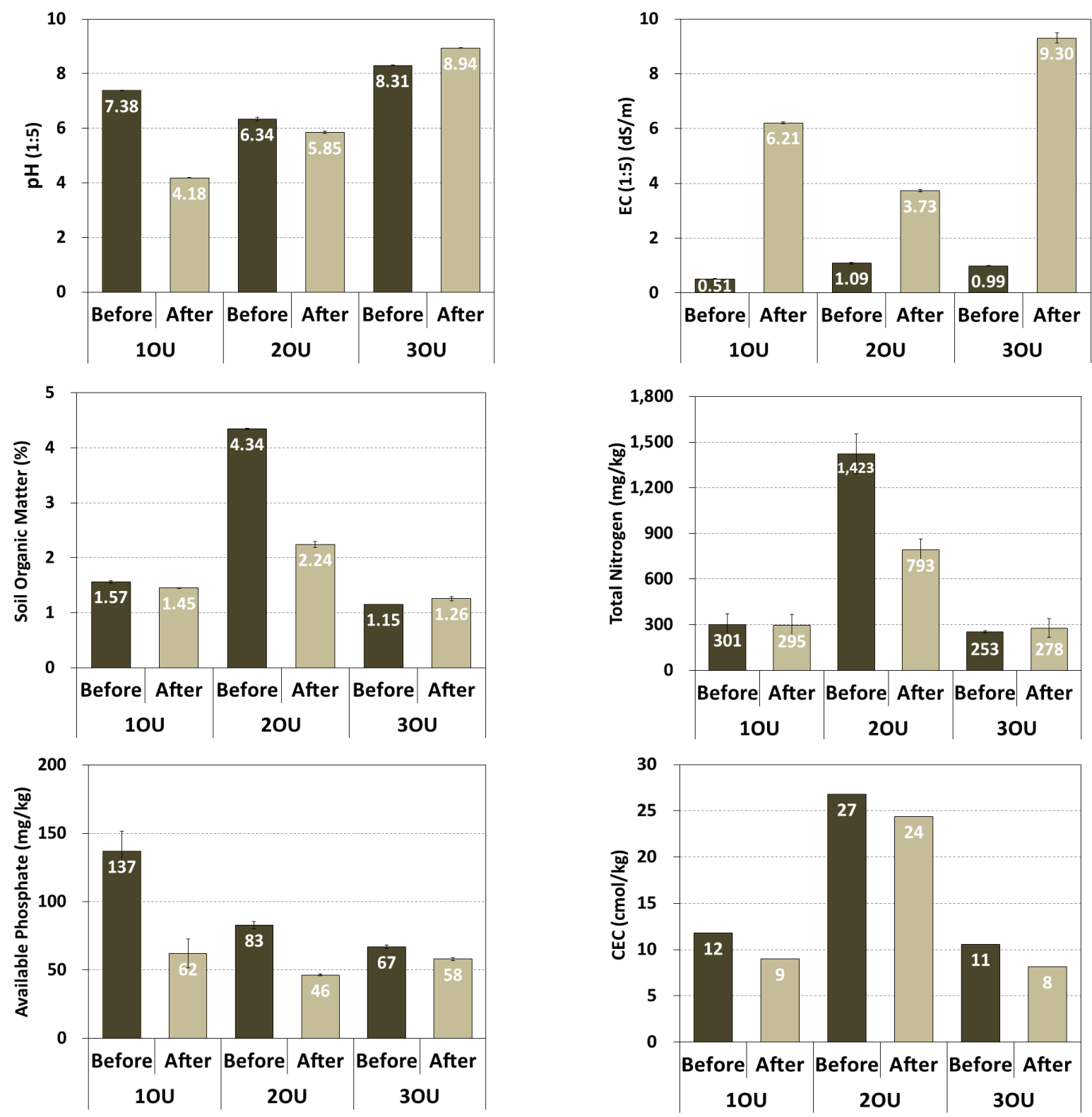

Fig. 2. Changes in soil chemical properties before and after washing of the Janghang Smelter related metal contaminated soil (from three different operation units; $10 \mathrm{U}, 20 \mathrm{U}$ and $30 \mathrm{U}$ ).

\section{3. 토양 질 평가}

본 연구에서는 옛 장항제련소 주변 중금속 오염토에 대한 세척 전, 후 토양의 질(soil quality)을 Table4에 제시한 장항 지역 작물별 시비처방기준과 비교하여 평가해 보았다. 세 척 전, 후 토양 분석 결과와 작물별 시비처방기준 9개 항목 최적 범위 값과 비교하여 “O”(적정: optimal), "E”(과다: excessive), "L"(부족: lack)으로 표기한 결과는 Table 5와 같 다. 그리고 Fig.4는 10U, 20U, 3OU 오염토 세척 전, 후 토 양 질 평가 결과 “적정”, “과다”, “부족” 각각에 해당하는 데이터 개수를 도시하였다.

옛 장항제련소 주변 중금속 오염토는 세척(정화) 후 토양 질이 떨어지는 것으로 나타났다. $1 \mathrm{OU}, 2 \mathrm{OU}, 3 \mathrm{OU}$ 를 모두
통틀어 집계하면 세척 전(오염토) “적정”범위에 속한 토양 특성 값은 10 개였지만 세척 후(세척토) 5 개로 줄었다. $1 \mathrm{OU}$ 는 세척 전 “적정”범위에 속한 토양특성 값이 4개였지만 세 척 후 1 개로 떨어졌다. 한편, 세척 전 “부족”토양 특성 값은 1 개에 불과했지만 세척 후 6 개로 늘어났다. $2 \mathrm{OU}$ 는 세척 전 “적정”범위에 속한 토양특성 값이 4개였지만 세척 후 3 개로 떨어졌고 $3 \mathrm{OU}$ 도 세척 전 “적정”범위에 속한 토양특성 값이 2 개였지만 세척 후 1 개로 떨어졌다.

세척 전, 후 토양 질 평가에서 가장 두드러지게 토양 특성 변화가 일어난 항목은 토양 전기전도도였다. 전기전도도는 3 개 $\mathrm{OU}$ 토양 모두 세척 전 “적정”범위였지만 세척 후 “과 다”로 변하였다. 다음으로 두드러지게 토양 질 변화를 나타 

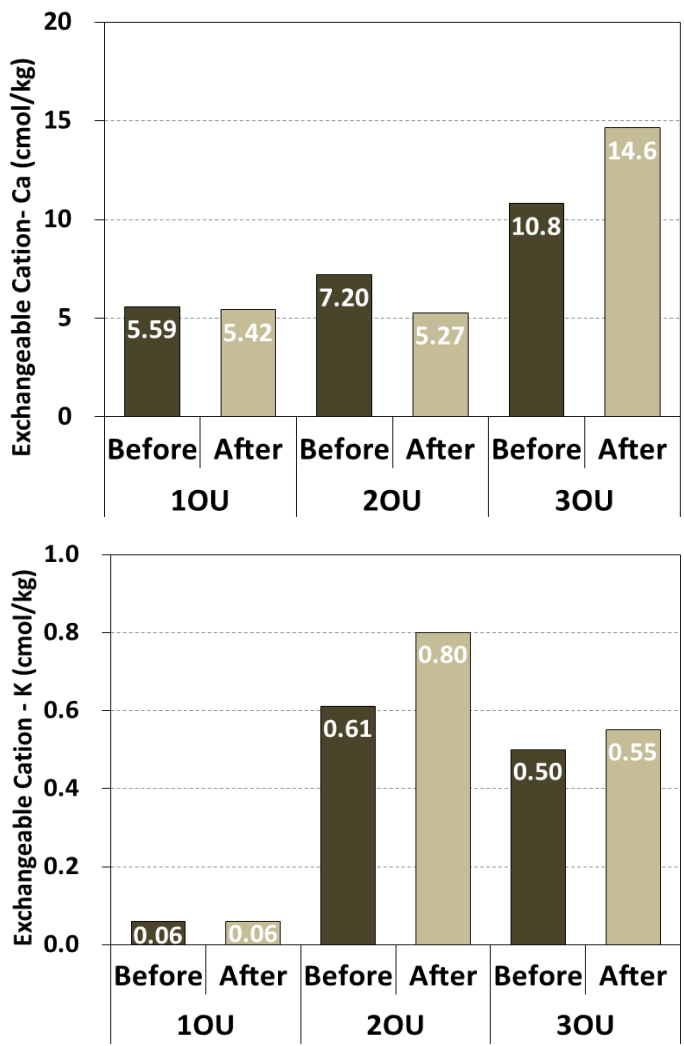
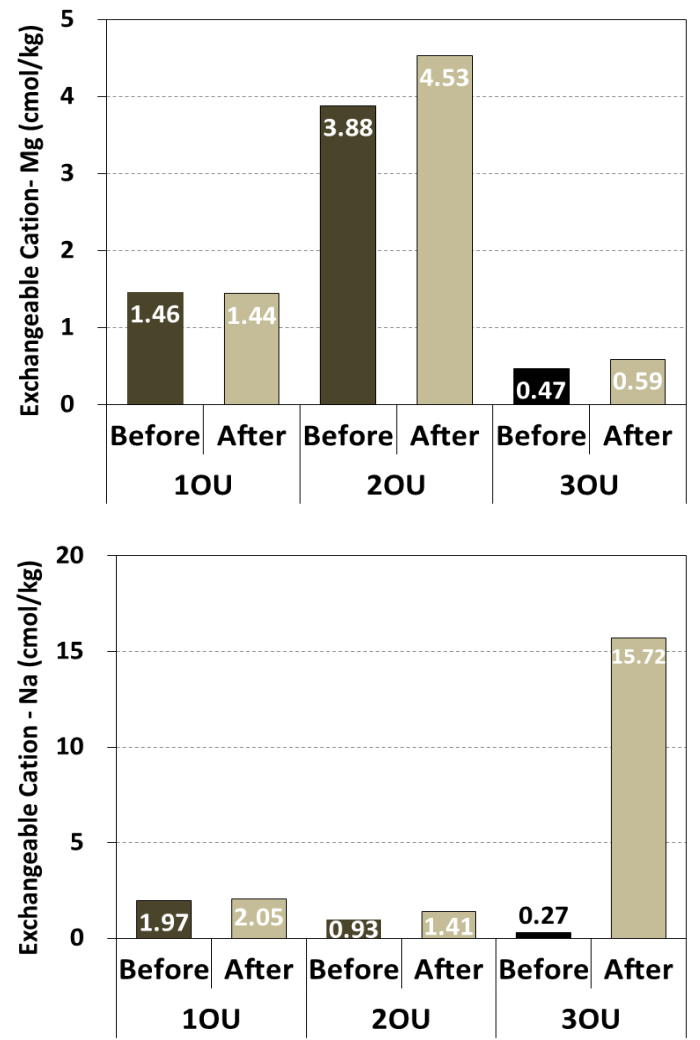

Fig. 3. Changes in exchangeable cation of soil before and after washing of the Janghang Smelter related metal contaminated soil (from three different operation units; 10U, 20U and 30U).

Table 5. Evaluation of soil analysis data before and after washing of the Janghang Smelter related metal contaminated soil with the soil fertilization prescription for Janghang agricultural crops selected from the guidelines suggested by KRDA (shown in Table 5).

\begin{tabular}{|c|c|c|c|c|c|c|c|c|c|c|}
\hline \multirow{2}{*}{\multicolumn{2}{|c|}{ Operation Unit }} & \multirow{2}{*}{$\mathrm{pH}(1: 5)$} & \multirow{2}{*}{ EC (1:5) } & \multirow{2}{*}{ OM } & \multirow{2}{*}{ AvP } & \multirow{2}{*}{ AvS } & \multirow{2}{*}{ CEC } & \multicolumn{3}{|c|}{ ExC } \\
\hline & & & & & & & & K & $\mathrm{Ca}$ & $\mathrm{Mg}$ \\
\hline \multirow{2}{*}{$10 U$} & before & $E$ & 0 & $\mathrm{~L}$ & 0 & - & 0 & L & 0 & $\mathrm{~L}$ \\
\hline & after & $\mathrm{L}$ & $E$ & L & L & - & $\mathrm{L}$ & $\mathrm{L}$ & 0 & $\mathrm{~L}$ \\
\hline \multirow{2}{*}{$20 U$} & before & 0 & 0 & $E$ & 0 & 0 & $E$ & $E$ & $E$ & $E$ \\
\hline & after & 0 & $E$ & 0 & L & $E$ & E & $E$ & 0 & $E$ \\
\hline \multirow{2}{*}{300} & before & $\mathrm{E}$ & 0 & L & $\mathrm{L}$ & - & $L$ & 0 & $E$ & $\mathrm{~L}$ \\
\hline & after & $E$ & $E$ & L & $\mathrm{L}$ & - & $\mathrm{L}$ & 0 & $E$ & $\mathrm{~L}$ \\
\hline
\end{tabular}

O-optimal, E-excessive, L-lack, EC: Electrical conductivity, OM: organic matter, AvP: available phosphate, AvS: available silicate (applied for paddy field), ExC: Exchangeable cation

낸 항목은 유효인산이다. $1 \mathrm{OU}$ 와 $2 \mathrm{OU}$ 모두 세척 전 “적정” 범위에서 “부족”으로 변화되었다.

토양세척법은 중금속 오염토 정화를 위해 가장 널리 사용 하는 공법으로 중금속이 집중되어 있는 미세토를 분류하여 폐기하는 목적과 중금속을 화학세척액으로 용해시켜 분리 하는 목적을 가지고 있다. ${ }^{28)}$ 따라서, 토양세척법은 미세토가 폐기되거나 화학세척액으로 인해 토양의 교란이 심히 나타 날 것으로 예상 ${ }^{29}$ 되는 바와 같이 옛 장항제련소 주변 중금 속 오염토 세척의 경우도 토양 질 변화가 이루어진 것으로
나타났다. 또한 세척 후 탈수를 위해 고농도 응집제를 사용 하거나 토양 $\mathrm{pH}$ 조정을 위해 고농도 염들이 투여되어 토양 전기전도도가 급격히 상승하게 되었다. 토양세척을 통해 중 금속 오염기준을 만족한 정화토라도 토양 건강성 측면에서 치유가 필요할 수 있다.

토양환경보전법 제 1 조 (목적)에는 “토양오염으로 인한 국 민건강 및 환경상의 위해를 예방하고 오염된 토양을 정화하 는 등 토양을 적정하게 관리 보전함으로써 토양생태계를 보 전하고 자원으로서의 토양가치를 높이며"로 명시되어 토양 


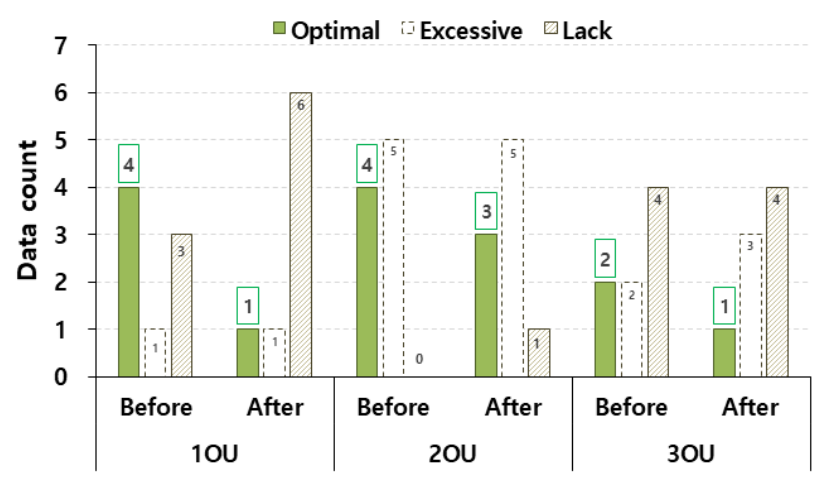

Flg.4. Variation in soil quality before and after washing of the Janghang Smelter related metal contaminated soil. Soil quality was evaluated by the soil fertilization prescription for Janghang agricultural crops suggested by KRDA (shown in Table 5).

을 되돌릴 수 없는 자원으로 가치를 높일 것을 천명하고 있 다. 그러나 우리나라 토양환경보전법의 토양환경관리는 현 재 토양오염기준에 의한 오염여부만을 관리하고 있으며 ${ }^{30}$ 정화가 완료된 정화토 재활용에 대한 어떠한 규정도 마련되 어 있지 않아 앞으로 이에 대한 대책이 필요하다. 본 연구에 서 제시한 결과와 같이 토양오염 정화공법 적용 이후 토양 은 심하게 교란되어 토양 고유의 기능을 잃어버리므로 생태 계의 중요한 일원으로 토양을 다시 되돌려 보내기 위해 토 양의 가치를 높이고 회복시키는 노력이 절실히 필요하다.

\section{4. 결 론}

1) 중금속 오염토 세척공정에서 세척 전, 후 토성(texture) 변화를 조사한 결과 투입된 오염토 토성에 따라 변화가 결 정된다. 사질성 토양의 경우 토양 파쇄 및 분쇄과정으로 토 성변화가 크게 나타났지만 미사질성 토양은 세척 후 토성 변화가 적었다. 사질성 토양인 $1 \mathrm{OU}, 3 \mathrm{OU}$ 는 굵은 모래가 파 쇄, 분쇄되어 가는 모래 함량과 실트질 토양함량이 상대적 으로 증가하였다. 반면, 미사질성 토양(논토양) 2OU는 세척 후에도 토성 변화가 없었다.

2) 사질성 토양은 점토 함량이 상대적으로 적은데다 세척 후 오히려 미세토가 빠져나가 용적밀도 증가, 보수력 감소, 입단의 안정성 감소를 보였다.

3) 세척 후 정화토의 $\mathrm{pH}$ 는 사용된 세척액에 따라 크게 영 향을 받았다. 산성용액을 세척액으로 사용한 $1 \mathrm{OU}$ 와 $2 \mathrm{OU}$ 는 확연히 낮은 $\mathrm{pH}$ 를 나타냈고 알칼리용액을 사용한 $3 \mathrm{OU}$ 의 $\mathrm{pH}$ 는 증가하였다.

4) 세척 후 토양의 유기물함량, 전질소, 유효인산 및 $\mathrm{CEC}$ 등은 세척 전 오염토에 비해 모두 감소하였다. 미사질 논토 양인 $2 \mathrm{OU}$ 의 유기물함량과 총질소 값은 세척 후 확연히 감 소하였다.
5) 세척 후 가장 두드러지게 변화한 토양 특성 값은 전기 전도도였다. 토양세척 전, 후 토양 전기전도도는 $1 \mathrm{OU} 0.51$ $\rightarrow 6.21 \mathrm{ds} / \mathrm{m}, \quad 2 \mathrm{OU} 1.09 \rightarrow 3.73 \mathrm{ds} / \mathrm{m}, 3 \mathrm{OU} \quad 0.99 \rightarrow 9.30$ $\mathrm{ds} / \mathrm{m}$ 로 모든 $\mathrm{OU}$ 에서 급격히 증가하였다. 세척 전 오염토양 의 전기전도도는 모두 적정수준인 $2 \mathrm{ds} / \mathrm{m}$ 이하였지만 토양 세척 후 크게 증가하여 강한 염류토양 수치를 보였다.

6) 장항지역 작물별 시비처방기준으로 옛 장항제련소 주 변 중금속 오염토 세척(정화) 전, 후 토양 질을 평가한 결과 세척 후 토양 질이 급격히 저하된 것으로 나타났다. $1 \mathrm{OU}$, 2OU, 3OU를 모두 통틀어 세척 전(오염토) “적정” 범위에 속한 토양 특성 값은 10 개였지만 세척 후(세척토) 5 개로 줄 었다.

7) 중금속 세척공정으로 인한 토양 질 변화 원인은 첫째, 중금속을 상대적으로 높게 함유한 미세토의 분리 및 폐기로 미세토가 빠져나간 것과 둘째, 화학세척액에 의한 토양교란 이 이루어졌고, 셋째, 응집제 및 중화제 등 고농도 염을 사 용하였기 때문이다. 따라서 정화토를 생태계의 일원으로 다 시 되돌려 보내기 위해 토양으로서 고유 기능을 회복시키고 자 하는 제도적 정비와 공학적 노력이 필요하다.

\section{Acknowledgements}

본 연구는 환경부, 한국환경산업기술원(GAIA2014000560 001, 지중환경RE201901175) 지원에 의해 수행되었습니다. 이에 감사드립니다.

\section{References}

1. Ministry of Environment, $2^{\text {nd }}$ Master Plan of Korean Soil Protection, Sejong, Korea(2020).

2. S. S. Andrews, D. L. Karlen, C. A. Cambardella, The soil management assessment framework: a quantitative soil auality evaluation method, Soil Sci. Soc. Am. J., 68(6), 1945-1962(2004).

3. D. E. Stott, S. S. Andrews, M. A. Liebig, B. J. Wienhold, D. L. Karlen, Evaluation of $\beta$-glucosidase activity as a soil quality indicator for the soil management assessment framework, Soil Sci. Soc. Am. J., 74(1), 107-119(2010).

4. Y. Min, K. Sung, Influence of washing treatment on the qualities of heavy metal-contaminated soil, Ecol. Eng., 81, 89-92(2015).

5. Y. Chae, R. Cui, S. W. Kim, G. An, S.-W. Jeong, Y.-J. An, Exoenzyme activity in contaminated soils before and after soil washing: ß-glucosidase activity as a biological indicator of soil health, Ecotoxicol. Environ. Saf., 135, 368-374(2017).

6. Y. Yoon, Y. Kang, Y. Chae, S. Kim, Y. Lee, S.-W. Jeong, Y.-J. An, Arsenic bioavailability in soils before and after soil washing: The use of Escherichia coli whole-cell bioreporters, Environ. Sci. Pollut. Res., 23(3), 2353-2361(2016).

7. Korean Government Ministry Consortium, Soil Remediation 
Plans for the former Janghang Smelter Area(2009).

8. NAAS(National Academy of Agricultural Science), Soil Physical Property Survey Methods and Analysis, Soil Fertilizers department in NAAS, Suwon city in Republic of Korea, pp. 83-89(2013).

9. Y. Yoon, S. Kim, Y. Chae, S.-W. Jeong, Y.-J. An, Evaluation of bioavailable arsenic and remediation performance using a whole-cell bioreporter, Sci. Total Environ., 547, 125-131(2016).

10. K. H. Tan, Soil Sampling, Preparation and Analysis, CRC Press(2005).

11. Y. Yoon, S. Kim, Y. Chae, S. W. Kim, Y. Kang, G. An, S.-W. Jeong, Y.-J. An, Simultaneous detection of bioavailable arsenic and cadmium in contaminated soils using dual-sensing bioreporters, Appl. Microbiol. Biotechnol., 100(8), 3713-3722(2016).

12. NRCS(Natural Resources Conservation Service), Soil Quality Test Kit Guides, pp. 18-19(2001).

13. Y. Yoon, S. Kim, Y. Chae, Y. Kang, Y. Lee, S.-W. Jeong, Y.-J. An, Use of tunable whole-cell bioreporters to assess bioavailable cadmium and remediation performance in soils, PLOS ONE, 11(5), https://doi.org/10.1371/journal.pone.015 4506(2016).

14. D. E. Harding, D. J. Ross, Some factors in low-temperature storage influencing the mineralisable nitrogen of soils, J. Sci. Food Agr., 15(12), 829-834(1964).

15. Y. Chaea, R. Cui, S. W. Kim, G. An, S.-W. Jeong, Y.-J. An, Exoenzyme activity in contaminated soils before and after soil washing: ß-glucosidase activity as a biological indicator of soil health, Ecotoxicol. Environ. Saf., 135, 368-374(2017).

16. MOE(Ministry of Environment), Soil Pollution Standard Method, Ministry of Environment, Republic of Korea, Sejong Metropolitan Autonomous city in Republic of Korea, pp. 26-31(2009).

17. KATS(Korean Agency for Technology and Standards), Standard test method of organic matter contents in soils by ignition loss, Machinery $\cdot$ Materials $\cdot$ Construction Standard department in KATS, Eumseong-gun in Republic of Korea, standard no. KS F 2104 of the KATS(2013).

18. NAAS(National Academy of Agricultural Science), Soil chemical analysis method, National Academy of Agricultural Science, Suwon city in Republic of Korea, pp. 41-172(2010).

19. S. W. Kim, Y. Chae, J. Moon, D. Kim, R. Cui, G. An, S.-W. Jeong, Y.-J. An, In situ evaluation of crop productivity and bioaccumulation of heavy metals in paddy soils after remediation of metal-contaminated soils, J. Agric. Food Chem., 65(6), 1239-1246(2017).

20. RDA(Rural Development Administration), Standard fertilization prescription of crops, Republic of Korea, 1-268(2010).

21. H. J. Cho, S. W. Hwang, K. H. Han, H. R. Cho, J. H. Shin, L. Y. Kim, Physicochemical properties of upland soils under organic farming, Kor. Soc. of soil Sci. \& Fert., 42(2), 98-102(2009).

22. P. J. Kim, D. K. Lee, D. Y. Chung, Effects of soil bulk density on saturated hydraulic conductivity and solute elution patterns, Kor. Soc. of soil Sci. \& Fert., 30(3), 234-241(1997).

23. S. W. Kim, D. Kim, J. Moon, Y. Chae, J. I. Kwak, Y. Park, S.-W. Jeong, Y.-J. An, Earthworm dispersal assay for rapidly evaluating soil quality, Environ. Toxicol. Chem., 36(10), 2766-2772(2017).

24. J. G. Son, J. Y. Cho, Effect of organic material treatments on soil aggregate formation in reclaimed tidelands, Kor. Soc. of soil Sci. \& Fert., 42(3), 201-206(2009).

25. B. K. Yun, P. K. Jung, S. J. Oh, S. K. Kim, I. S. Ryu, Effects of compost application on soil loss and physico-chemical properties in lysimeters, Kor. Soc. of soil Sci. \& Fert., 29(4), 336-341(1996).

26. J. I. Kwak, S.-H. Nam, S. W. Kim, R. Bajagain, S.-W. Jeong, Y.-J. An, Changes in soil properties after remediation influence the performance and survival of soil algae and earthworm, Ecotoxicol. Environ. Saf., 174, 189-196(2019).

27. I. W. Ko, Y. Y. Chang, C. H. Lee, K. W. Kim, Assessment of pilot-scale acid washing of soil contaminated with As, $\mathrm{Zn}$ and $\mathrm{Ni}$ using the BCR three-step sequential extraction, J. Hazard. Mater., 127, 1-13(2005).

28. Y. Gwon, S. R. Kim, E. J. Kim, Effect of soil washing using oxalic acid on arsenic speciation and bioaccessibility in soils, J. Korean Soc. Environ. Eng., 42(4), 218-227(2020).

29. S. W. Kim, S.-W. Jeong, Y.-J. An, Application of a soil quality assessment system using ecotoxicological indicators to evaluate contaminated and remediated soils, Environ. Geochem. Health, 42(6), 1681-1690(2020).

30. S. Lee, J. Kim, S.-W. Jeong, Analysis of the organic matter content for soil samples taken at the new points of Korea soil auality monitoring network, J. Korean Soc. Environ. Eng., 38(12), 641-646(2016).

\section{Authors}

\section{Keong-Hyeon An}

Department of Environmental Engineering, Kunsan National University, Ph.D. Student, ORCID(10 0000-0001-5754-0348

\section{Songhee Kim}

Department of Environmental Engineering, Kunsan National University, Master Course Student, ORCID (C) 0000-0002-4181-8410

\section{Seung-Woo Jeong}

Department of Environmental Engineering, Kunsan National University, Professor, ORCID(D) 0000-0001-7418-4576 